\title{
WATER EROSION UNDER SIMULATED RAINFALL IN DIFFERENT SOIL MANAGEMENT SYSTEMS DURING SOYBEAN GROWTH
}

\author{
Fernando Luis Engel ${ }^{1}$; Ildegardis Bertol ${ }^{1 *}$; Álvaro Luiz Mafra ${ }^{1}$; Neroli Pedro Cogo $^{2}$ \\ ${ }^{1}$ UDESC/CAV - Depto. de Solos, Av. Luiz de Camões, 2090, Bairro Conta Dinheiro - 88520-000 - Lages, SC - \\ Brasil. \\ ${ }^{2}$ UFRGS/FA - Depto. de Solos, Av. Bento Gonçalves, 7712 - 91501-970 - Porto Alegre, RS - Brasil. \\ *Corresponding author <a2ib@cav.udesc.br>
}

\begin{abstract}
Soil management influences soil cover by crop residues and plant canopy, affecting water erosion. The objective of this research was to quantify water and soil losses by water erosion under different soil tillage systems applied on a typical aluminic Hapludox soil, in an experiment carried out from April 2003 to May 2004, in the Santa Catarina highland region, Lages, southern Brazil. Simulated rainfall was applied during five soybean cropstages, at the constant intensity of $64.0 \mathrm{~mm} \mathrm{~h}^{-1}$. Treatments were replicated twice and consisted of: i) conventional tillage on bare soil - control treatment (CTBS), ii) conventional tillage on cultivated soil (CTCS), iii) no-tillage on non tilled soil with burned crop residue (NTRB), iv) no-tillage in non tilled soil with crop residue desiccated (NTRD), and v) no-tillage on fouryears interrupted soil tillage with crop residue desiccated - "traditional no tillage" (NTRT). Regardless of soybean cropstages, water losses were the highest for the CTCS than for the untilled soils, while soil losses were considerably higher in the CTCS treatment only until cropstage 3 , in cultivated soil treatments. The NTRT was most effective treatment in terms of both water and soil loss reduction. Water infiltration should also be considered, when considering the soil erosion process caused by rainfall and its associated runoff, due to the management systems usually adopted in cultivated fields.
\end{abstract}

Key words: soil cover, soil loss, water loss, soybean crop

\section{EROSÃO HÍDRICA SOB CHUVA SIMULADA EM DIFERENTES SISTEMAS DE MANEJO DO SOLO DURANTE O CRESCIMENTO DA SOJA}

\begin{abstract}
RESUMO: O manejo do solo influencia a cobertura superficial pelo resíduo cultural e, juntamente com a cobertura do solo pela copa das plantas, afeta a erosao hídrica. O objetivo do estudo foi quantificar as perdas de água e solo por erosão hídrica em diferentes sistemas de manejo do solo, em diferentes estádios do cultivo da soja, em um experimento conduzido de abril de 2003 a maio de 2004, na região do Planalto Catarinense, em um Nitossolo Háplico alumínico. Chuvas simuladas foram aplicadas em cinco estádios do cultivo da soja, com intensidade constante de $64 \mathrm{~mm} \mathrm{~h}^{-1}$. Os tratamentos, em duas repetições, consistiram de: i) preparo convencional sem cultivo do solo - tratamento testemunha (SC); ii) preparo convencional com cultivo do solo (PC); iii) semeadura direta sobre resíduo cultural queimado, em solo nunca preparado (SQ); iv) semeadura direta sobre resíduo cultural dessecado, em solo nunca preparado (SD); e v) semeadura direta sobre resíduo cultural dessecado, em solo preparado quatro anos antes, denominada semeadura direta tradicional (ST). Independentemente dos estágios da soja, as perdas de água foram maiores no tratamento PC do que nos sem preparo do solo, enquanto as perdas de solo foram consideravelmente maiores no tratamento PC somente no estágio 3, nos tratamentos de solo cultivado. O ST foi o tratamento mais eficaz no estudo, em termos de redução das perdas de água e solo. Em se tratando da relação da erosão hídrica do solo com sistemas de manejo usualmente empregados nas lavouras, outras variáveis, deveriam ser consideradas, tais como a infiltração de água no solo.

Palavras-chave: cobertura do solo, perda de solo, perda de água, cultura da soja
\end{abstract}

\section{INTRODUCTION}

Tillage breaks soil aggregates, increases surface roughness, and diminishes the soil surface cover by crop residues, thus reducing resistance to water erosion. On the other hand, absence of tillage preserves soil structure and maintains its surface covered by crop residues, protecting the soil from water erosion, in spite of reducing surface roughness. 
Conventional tillage associated with burning previous crop residues can increase soil susceptibility in relation to erosion, in spite of increasing soil surface roughness and total porosity in the plowed layer (Allmaras et al., 1966; Cogo et al., 1984; Bertol et al., 1997). As a result, both surface water retention and infiltration are higher, especially in recently-tilled soil, generally as compared to untilled soils (Cogo et al., 1984). On the other hand, no-tillage keeps crop residues on soil surface, and usually leads toward soil consolidation, increasing the soil resistance to water erosion (Cogo et al., 1984; Mello et al., 2003; Leite et al., 2004).

Soil cover by crop residues is the single variable that most influences water erosion, since it dissipates energy from raindrops right at the soil surface and reduces the velocity of surface runoff (Cogo, 1981; Foster, 1982). The effect that plant canopy soil cover has on reducing erosion during crop growth is less than the effect of dead crop residues (Wischmeier \& Smith, 1978) and will depend on many factors, such as plant type, stage, density, and crop sequence. Soil cover by plant canopies has generally higher effects in reducing water erosion under conventional tillage than under notillage system (Engel, 2005). Under a constant rainfallevent, soil losses by erosion will progressively decrease along the crop cycle, especially under conventional tillage (Levien et al., 1990; Engel, 2005).

The objective of this research was to quantify water and soil losses by water erosion, under distinct soil tillage systems, in different cropstages of soybean.

\section{MATERIAL AND METHODS}

This research was carried out in the field, from April, 2003 to May, 2004, in an experimental area located in the Santa Catarina highland region, Lages, southern Brazil, lying between $28^{\circ} 55^{\prime} 44^{\prime \prime}$ (S) and $51^{\circ} 08^{\prime} 32^{\prime \prime}(\mathrm{W})$. The mean altitude of the region is 846 $\mathrm{m}$, with a moist subtropical climate, according to Köppen's classification, and the mean annual precipitation is of the order of $1,600 \mathrm{~mm}$. The soil of the experimental area is a typical, aluminic Hapludox, with $16.5 \%$ slope, $680 \mathrm{~g} \mathrm{~kg}^{-1}$ of clay, $210 \mathrm{~g} \mathrm{~kg}^{-1}$ of silt, and $110 \mathrm{~g} \mathrm{~kg}^{-1}$ of sand in the A horizon, and $592 \mathrm{~g} \mathrm{~kg}^{-1}$ of clay, $293 \mathrm{~g} \mathrm{~kg}^{-1}$ of silt, and $115 \mathrm{~g} \mathrm{~kg}^{-1}$ of sand in the B horizon. Under natural conditions, this soil presents a mean organic carbon content of $10.6 \mathrm{~g} \mathrm{~kg}^{-1}$ in the A horizon and $2.9 \mathrm{~g} \mathrm{~kg}^{-1}$ in the B horizon (Mello et al., 2003).

From September 1999 to March 2003, the experimental area was used for several soil erosion studies under simulated rainfall. Details about tillage methods and cropping practices used in this experimental period can be found in Mello et al. (2003) and Leite et al. (2004). In April 2003, the experimental area was seeded to fodder radish (Raphanus sativus), with the purpose to produce aerial biomass for the present study, except the portion reserved for the plots for the control treatment (uncultivated, conventionally-tilled). No limestone or fertilizers were applied to the plots. In the no-tillage treatment, fodder radish seeds were manually distributed over the soil surface, immediately before harvesting the previous corn crop (Zea mays), with the residues being manually laid down over the fodder radish seeds. In the area used for the plots conventionally-tilled, cultivated soil treatment, fodder radish seeds were also manually distributed over the soil surface, immediately after tillage, being incorporated into the soil by manually dragging a tree log over the seeds. In October 2003, at the full flowering cropstage, the fodder radish was chemically desiccated, yielding about $4 \mathrm{Mg} \mathrm{ha}^{-1}$ of dry aerial biomass. This crop residue was then entirely left on the soil surface for two no-tillage treatments, partially burned for another no-tillage treatment, and incorporated into the soil for the conventionally-tilled, cultivated soil treatment, as better specified below. These management forms for the fodder radish crop residue were established in duplicate, at the very end of October 2003, to plant the soybean crop (Glycine max) for this research.

The soil tillage systems consisted of: i) conventional tillage on bare soil, continuously uncultivated - control treatment (CTBS); ii) conventional tillage on soil continuously cultivated with crop residue incorporated into the plow layer (CTCS); iii) no-tillage, continuously cultivated, on never-tilled soil with crop residue partially burned and left on the surface (NTRB); iv) no-tillage, continuously cultivated, on never-tilled soil with crop residue chemically desiccated and left on the surface (NTRD); and v) no-tillage, continuously cultivated, 4-years interrupted soil tillage with crop residue chemically desiccated and left on the surface - previously referred to as traditional no tillage (NTRT). Soil tillage in CTBS and CTCS treatments was performed by plowing the soil once and disking it twice, respectively to the 0.18 to $0.20 \mathrm{~m}$ and 0.12 to $0.15 \mathrm{~m}$ soil depths, along the slope direction. No-tillage treatments were sown using a no-till planter machine, provided with an unlined, double-disk seed opener. This machine simultaneously places fertilizers and seeds into the soil. Soybean was seeded at a spacing of $0.5 \mathrm{~m}$, placing 18 seeds per linear meter, in the direction of tillage (upand-down slope), at the beginning of November 2003. Fertilizers applied at the time of planting consisted of $142 \mathrm{~kg} \mathrm{ha}^{-1}$ of triple phosphate and $150 \mathrm{~kg} \mathrm{ha}^{-1}$ of potassium chloride. Weeds were manually controlled throughout the experimental period. 
Artificial rain was applied with a rotating-boom rainfall simulator (Swanson, 1975), capable of simultaneously spraying water on two, contiguous $3.5 \mathrm{u}$ $11.0 \mathrm{~m}$ erosion-plots, installed according to EMBRAPA (1975). Five rainfall tests were applied over the experimental period, one in each of the pre-established soybean cropstages $(1,2,3,4$, and 5 respectively corresponding to $5,3060,90$, and 120 days after soybean planting). Each rainfall test was made up of a constant, $64 \mathrm{~mm} \mathrm{~h}^{-1}$ rainfall intensity (equivalent to 0.2083 $\mathrm{MJ} \mathrm{ha}{ }^{-1} \mathrm{~mm}^{-1}$ ), for 1 hour. The soil was pre-wetted to field capacity 24-hours prior to the establishment of each rainfall treatment using the same rainfall simulator and the same rainfall intensity.

Both, soil cover by surface crop residue using the meter-stick method (Hartwig \& Laflen, 1978), and soil cover by soybean plant canopies using the meter-shaded method (Adams \& Arkin, 1977), were measured immediately before each rainfall test. Gravimetric soil water content was measured for the 0 to $0.20 \mathrm{~m}$ soil layer. Time of the beginning of runoff was taken with a chronometer. After surface flow appearence, runoff samples were manual and intermittently collected, at 3-min intervals, using a graduated cylinder, in order to perform computations of runoff rates, sediment concentration, and water and soil losses by runoff. These runoff measurements were made following the procedures described in Cogo (1981).

Results of soil cover, time of runoff start, steady runoff rate, water loss, sediment concentration in runoff, and soil loss were interpreted by analysis of variance. The means were compared by the Duncan test $(P<0.05)$, and critical ranges between treatments in each soybean cropstages (rainfall test), and between cropstages in each treatment were individually presented.

\section{RESULTS AND DISCUSSION}

\section{Soil cover by crop residue and by soybean plant canopies}

Soil cover by the fodder radish crop residue was different only when comparing tilled-versus untilled-soil treatments (Figure 1). Soil cover by crop residue in any of the untilled-soil treatments was little reduced throughout the experimental period, ending up with values in the order of $75 \%$ to $85 \%$ of the existing at the time the experiment was initiated. However soil cover by crop residue in the NTRD and NTRT treatments were low as compared to those commonly observed for other common, annual row-crops (Leite et al., 2004). This could be due to the relatively low quantity of fodder radish crop residue produced in the experiment $\left(4.0 \mathrm{Mg} \mathrm{ha}^{-1}\right)$, to crop type, and to lack of

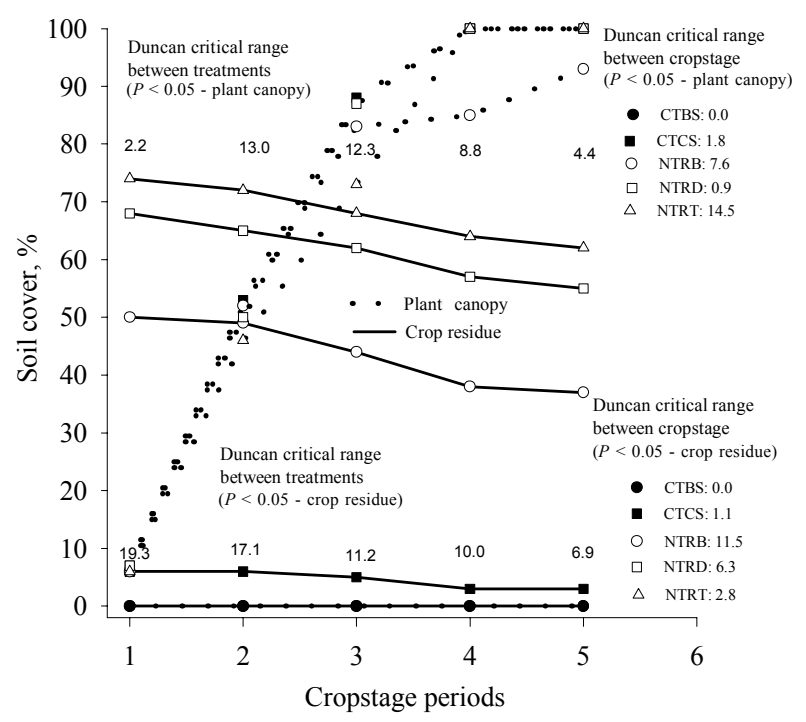

Figure 1 - Soil cover by fodder radish crop residue and by soybean plant canopy: CTBS: conventional tillage on bare soil (control treatment); CTCS: conventional tillage on cultivated soil; NTRB: no-tillage on never-tilled soil with burned crop residue; NTRD: no-tillage on nevertilled soil with desiccated crop residue; NTRT: notillage on four-year interrupted soil tillage with desiccated crop residue - "traditional no-tillage".

lime and fertilizer application at planting time. Soil cover data of about the same type as those obtained in this study, as far as soil erosion by water-rainfall is concerned, were also reported by Vieira et al. (1978), Cogo (1981), Levien et al. (1990), Bertol (1995), Mello et al. (2003), Leite et al. (2004), and Engel (2005).

Crop residue soil cover in the NTRB treatment was considerably lower than observed in NTRD and NTRT treatments, which can be regarded as high (Figure 1). This is most likely due to some crop residue of the fodder radish not completely burned and remaining firmly fixed on the soil surface in the NTRB treatment.

Soybean canopy coverage progressively increased with crop growth until cropstage 3 (60-days after planting) reaching 80 to $100 \%$ of soil cover regardless of the treatment (Figure 1).

\section{Time of runoff start}

The time of runoff start differed considerably among soil tillage systems and soybean cropstages (Figure 2). Values for this variable were highest for the NTRT treatment, raging from 24 minutes during cropstage 2 , to 33 minutes, for cropstage 1 , and the lowest for the CTBS treatment (ranging from $8 \mathrm{~min}$ utes, for cropstage 5, to 20 minutes, for cropstage 1). The time of runoff start for the CTCS treatment 
ranged from 15 minutes for cropstage 2, to 22 minutes for cropstage 5 . These differences were mainly caused due to the effects of management practices, given that the soil moisture prior to rainfall simulation was homogeneous (ranging from $0.26 \mathrm{~g} \mathrm{~g}^{-1}$ to $0.28 \mathrm{~g} \mathrm{~g}^{-1}$ at the 0 to $0.20 \mathrm{~m}$ soil depth) due to prewetting.

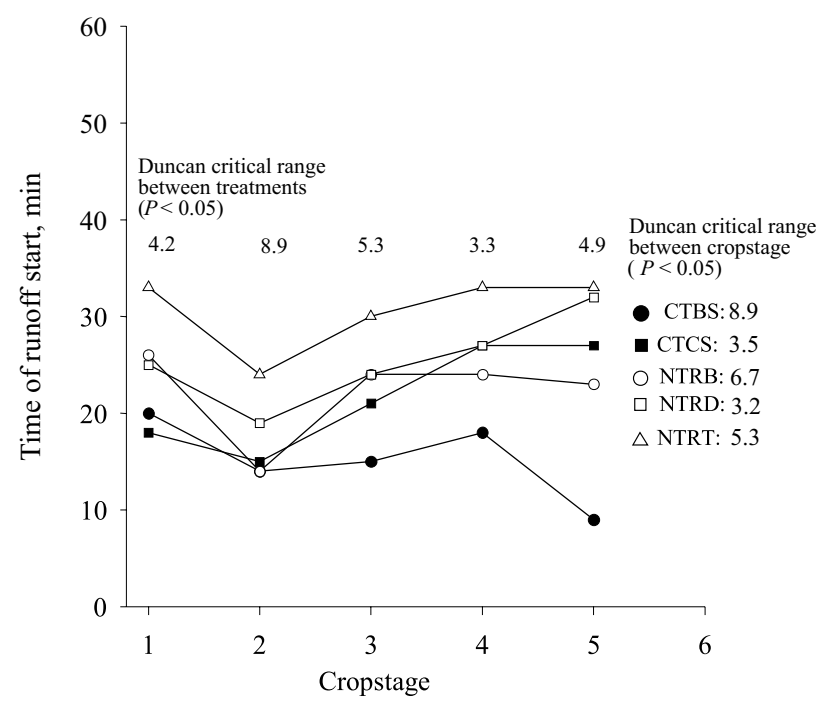

Figure 2 - Time to the start of runoff: CTBS: conventional tillage on bare soil (control treatment); CTCS: conventional tillage on cultivated soil; NTRB: no-tillage on nevertilled soil with burned crop residue; NTRD: no-tillage on never-tilled soil with desiccated crop residue; NTRT: no-tillage on four-year interrupted soil tillage with crop residue - "traditional no-tillage".

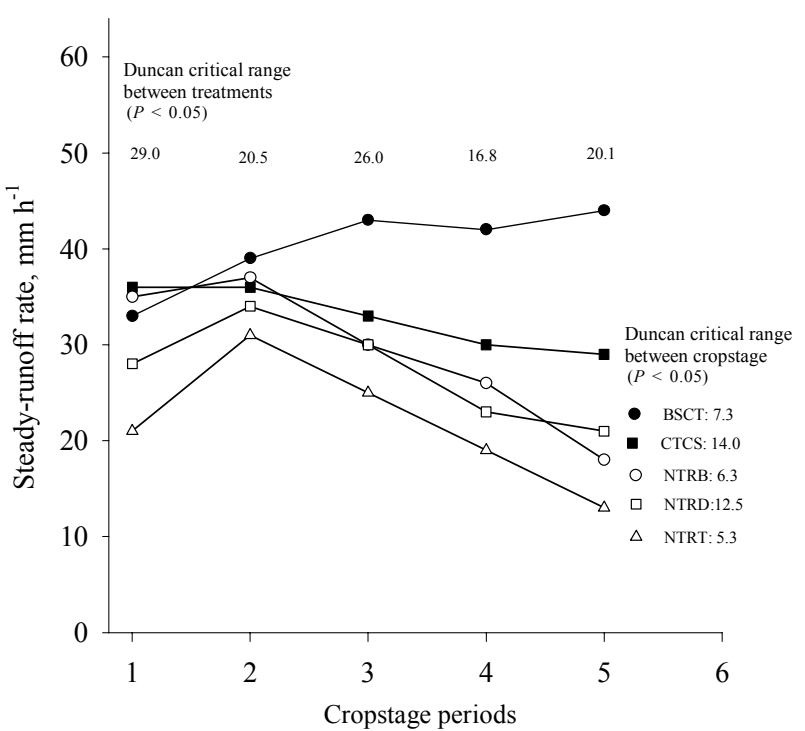

Figure 3 - Steady-runoff rates CTBS: conventional tillage on bare soil (control treatment); CTCS: conventional tillage on cultivated soil; NTRB: no-tillage on nevertilled soil with burned crop residue; NTRD: no-tillage on never-tilled soil with desiccated crop residue; NTRT: no-tillage on four-year interrupted soil tillage with crop residue - "traditional no-tillage".
Except for soybean cropstages 1 to 2 , in which the time of runoff start sharply decreased, values for this variable for the CTCS, NTRD, and NTRT treatments increased with advancing soybean cropstages (Figure 2), probably due to increased soil protection provided by the rainfall interception capacity of the soybean plant canopies as the crop grew (Figure 1).

\section{Surface runoff}

Among cultivated-soil treatments, the CTCS treatment presented higher runoff rates than NTRT, only at the last soybean cropstage (Figure 3). Under some conditions, runoff rates can be related to infiltration rates in saturated soils where microdepressions are filled with water (Cogo, 1981; Cogo et al., 1984).

Regardless of the soil tillage systems, runoff rates sharply increased from soybean cropstage 1 to cropstage 2, after which they sharply decreased, except for the control treatment, which maintained high runoff rates at all times with some differences between treatments (Figure 3). The decrease in runoff rates observed in some cultivated-soil treatments with advancing soybean cropstages means that conditions for infiltration and canopy interception improved as the crop grew, due to increased interception provided by the crop canopy and improved internal drainage provided by the expanding root system.

Water losses caused by runoff were similar among treatments during the first three soybean cropstages (Figure 4). Afterwards, the highest water losses were observed for the CTBS treatment, and the lowest for NTRT. These results were similar to the time of runoff start data (Figure 3). Considering both, total rainfall amount applied during each soybean cropstage $(64 \mathrm{~mm})$ and the crop water requirements, water losses in the cultivated-soil treatments remained in the range of 15 to $31 \mathrm{~mm}$, which are equivalent to $23 \%$ and $48 \%$ of the applied rainfall, respectively. Based on these findings, one may conclude that soilphysical conditions for water infiltration in the evaluated soil tillage systems treatments were unsatisfactory. Nevertheless, different crop sequences and/or crop species may improve the soil structure and its consequent ability to absorb rainfall.

Water losses in the form of surface runoff were greatly influenced by soil tillage systems (Figure 4), as also reported by Vieira et al. (1978), Levien et al. (1990), and Leite et al. (2004). These studies show that, as far as water losses due to erosion are concerned, both surface (e.g. residue cover, tillage-induced roughness, and canopy cover to some extent) and subsurface (e.g. degree of consolidation or loosening of the soil surface and internal porosity of the 


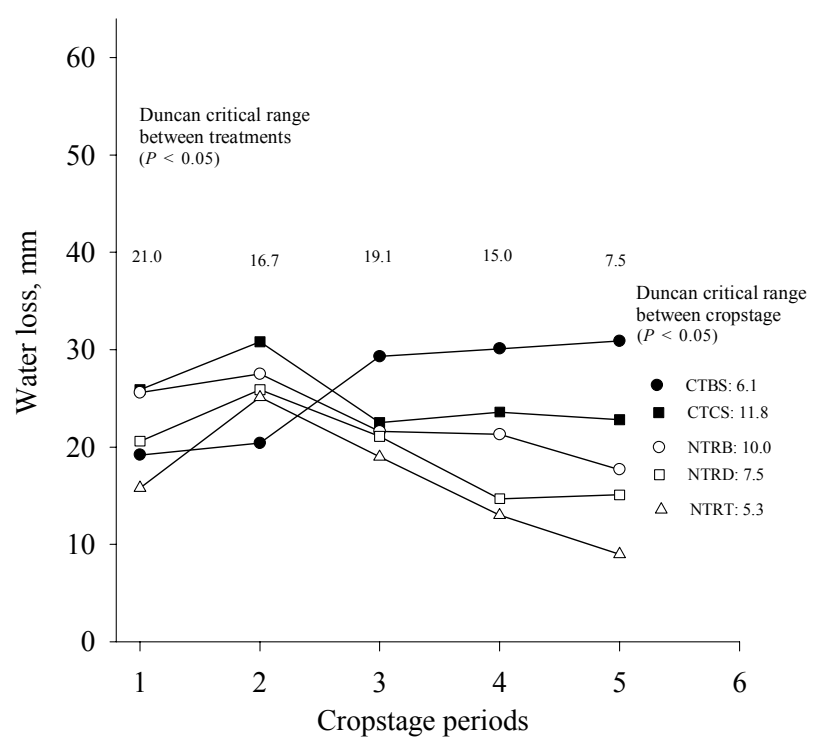

Figure 4 - Total water loss in the form of surface runoff: CTBS: conventional tillage on bare soil (control treatment); CTCS: conventional tillage on cultivated soil; NTRB: no-tillage on never-tilled soil with burned crop residue; NTRD: no-tillage on never-tilled soil with desiccated crop residue; NTRT: no-tillage on four-year interrupted soil tillage with crop residue - "traditional no-tillage".

soil mass) soil physical conditions associated with management practices are important considerations. However, because the combined effect of such variables is influenced by many interactions, it is difficult to assess which of them play the most important part in the erosion process (Allmaras et al., 1966; Wischmeier \& Smith, 1978).

\section{Runoff sediment concentration}

Values for mean sediment concentration in runoff varied for soil tillage systems and soybean cropstages, especially between tilled, uncovered soil and tilled, covered soil (Figure 5). Distinctly high sediment concentrations were observed in the CTBS (control) treatment with a large increase by the time corresponding to cropstages 1 and 2 to cropstages 3 to 5 . This increase in mean sediment concentration was due to the regular conventional tillage performed during cropstage 1 and scarification during all other cropstages. This later manner of soil preparation caused it to become finely fragmented, facilitating the detachment and transportation of soil particles by both rainfall and associated runoff.

A relatively high mean sediment concentration was observed for the CTCS treatment, during cropstages 2 and 3 (Figure 5), when plant canopies were not yet satisfactorily protecting the soil, and the almost complete absence of residue cover in this treat-

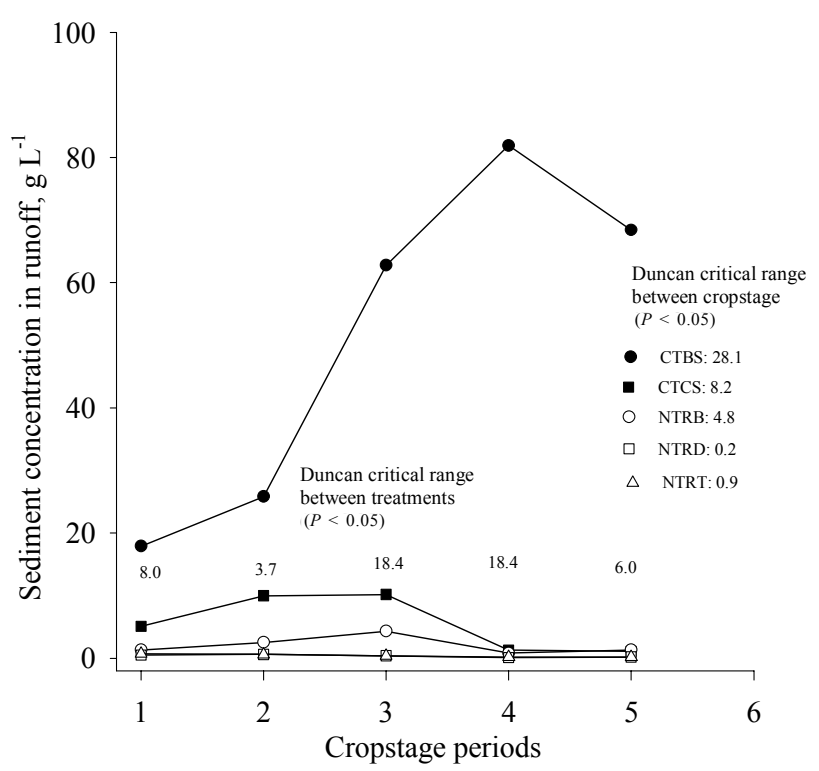

Figure 5 - Mean sediment concentration in the runoff water: CTBS: conventional tillage on bare soil (control treatment); CTCS: conventional tillage on cultivated soil; NTRB: no-tillage on never-tilled soil with burned crop residue; NTRD: no-tillage on never-tilled soil with desiccated crop residue; NTRT: no-tillage on four-year interrupted soil tillage with crop residue "traditional no-tillage".

ment (average of $4 \%$ soil cover across all cropstages, see Figure 1). The comparatively low values of mean sediment concentration in the runoff water observed in the untilled soils, regardless of soybean cropstage, are mainly explained by the presence of a relatively thick residue soil cover ( $55 \%$, on average), as a result of the previous fodder radish crop.

\section{Soil losses}

Regardless of soil tillage systems and soybean cropstages, all soil management treatments presented the same relative magnitude of mean sediment concentration in the runoff water (Figure 5). Soil losses between treatments (Figure 6) were much less influenced by treatment conditions than were water losses (Figure 4). The control treatment presented a high variation in soil losses, from $5.5 \mathrm{Mg} \mathrm{ha}^{-1}$ by the time of soybean cropstage 1 , to $31.0 \mathrm{Mg} \mathrm{ha}^{-1}$ at cropstage 4. Soil losses were relatively low (at most 3.0 $\mathrm{Mg} \mathrm{ha}^{-1}$ for the CTCS treatment, and $1.0 \mathrm{Mg} \mathrm{ha}^{-1}$ for the untilled soils NTRB treatment) with no difference between soybean cropstages. These results are consistent with the expected relationship between soil erosion and soil cover, for most crop residues and/or growing plants, the more protection the soil has against the erosive forces of both, rainfall and its associated runoff (Cogo, 1981; Bertol et al., 1997). 


\section{Overall soil loss-reduction effectiveness of treat- ments}

The relative effectiveness of the treatments was assessed by dividing the total soil loss in all cropstages by the total soil loss for the control treatment, for a period corresponding to the cropstages. The untilled soil treatments were relatively ineffective in reducing erosion ( $98.4 \%$ on average), in relation to the efficacy of soil conventional tillage which showed an effectiveness of $86.6 \%$ (Table 1). These relative soil loss results should be interpreted considering two important aspects. First, there are

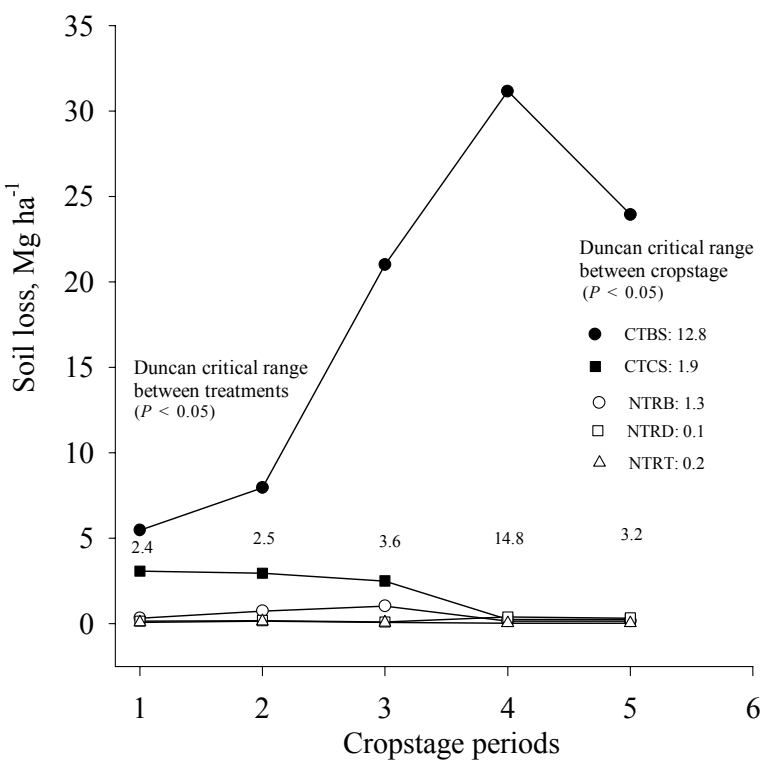

Figure 6 - Total soil loss by rainfall erosion: CTBS: conventional tillage on bare soil (control treatment); CTCS: conventional tillage on cultivated soil; NTRB: notillage on never-tilled soil with burned crop residue; NTRD: no-tillage on never-tilled soil with desiccated crop residue; NTRT: no-tillage on four-year interrupted soil tillage with crop residue - "traditional no-tillage". critical slope-length limits for full effectiveness of crop residues under conservation tillage systems for water erosion control, which are in general larger than 100 meters (Bertol et al., 1997; Morais \& Cogo, 2001), and the plot slope lengths in this study were too short (11 meters) when compared to slopelengths in farm conditions. Second, water storage in the soil is an important variable in the conservation soil and water systems. In some situations, untilled soils may lose more water in the form of surface runoff than do tilled soils, especially if conventional tillage is not the main tillage-method used in the system.

\section{CONCLUSIONS}

Soil losses were well explained by the previous crop residue cover, plant canopy cover, and tillage type, while differences in the time of runoff start, runoff rate, and water loss between treatments were less related to these factors. It is recommended that future research on the relationship between tillage type, soil moisture conservation and soil erosion consider also other variables than those here used, such as water infiltration into the soil.

Variation in soil loss between soil tillage systems (except the control treatment) and soybean cropstages was small as compared to the variation in the time of runoff starts, steady-runoff rate, and water loss.

The overall relative soil loss-reduction effectiveness was highest for the untilled soils and similar for the conventionally-tilled soil, consistent with the characteristics of each treatment under which the erosion process by rainfall and its associated runoff took place.

Table 1 - Total, absolute and relative soil losses observed over the entire experimental period (summed over soybean cropstages) as a function of soil tillage systems.

\begin{tabular}{lcc}
\hline Treatment & Absolute & Relative \\
\hline Conventional tillage bare soil - CTBS & $\mathrm{Mg} \mathrm{ha}^{-1}$ & $\%$ \\
\hline Conventional tillage with crop residue incorporated - CTCS & $65.6 \mathrm{~A}$ & 84.6 \\
No-tillage with crop residue partially burned - NTRB & $8.8 \mathrm{~B}$ & 11.0 \\
No-tillage with crop residue desiccated - NTRD & $2.3 \mathrm{~B}$ & 3.0 \\
No-tillage traditional - NTRT & $0.5 \mathrm{~B}$ & 0.6 \\
Mean & $0.3 \mathrm{~B}$ & 0.4 \\
Coefficient of variation (\%) & 15.5 & - \\
Soil total loss & 51.0 & - \\
\hline
\end{tabular}

Sci. Agric. (Piracicaba, Braz.), v.64, n.2, p.187-193, March/April 2007 


\section{REFERENCES}

ADAMS, J.E.; ARKIN, G.F. A light interception method for measuring row crop ground cover. Soil Science Society of America Journal, v.41, p.789-792, 1977.

ALLMARAS, R.R.; BURWELL, R.E.; LARSON, W.E.; HOLT, R.F. Total porosity and random roughness of the interrow zones influenced by tillage. Washington: USDA, 1966. 14p. (Conservation Research Report, 7)

BERTOL, I. Comprimento crítico de declive para preparos conservacionistas de solo. Porto Alegre: UFRGS, 1995. 185p. (Tese - Doutorado).

BERTOL, I.; COGO, N.P.; LEVIEN, R. Comprimento crítico de declive em sistemas de preparos conservacionistas de solo. Revista Brasileira de Ciência do Solo, v.21, p.139-148, 1997.

BERTOL, I.; COGO, N.P.; LEVIEN, R. Erosão hídrica em diferentes preparos do solo logo após as colheitas de milho e trigo, na presença e na ausência dos resíduos culturais. Revista Brasileira de Ciência do Solo, v.21, p.409-418, 1997.

COGO, N.P. Effect of residue cover, tillage induced roughness, and slope length on erosion and related parameters. West Lafayette: Purdue University, 1981. 346p. (Doctor - Thesis).

COGO, N.P.; MOLDENHAUER, W.C.; FOSTER, G.R. Soil loss reductions from conservation tillage practices. Soil Science Society of America Journal, v.48, p.368-373, 1984.

EMPRESA BRASILEIRA DE PESQUISA AGROPECUÁRIA EMBRAPA. Recomendações gerais do encontro sobre uso do simulador de chuva em pesquisa de conservação do solo no Brasil. In: ENCONTRO NACIONAL SOBRE PESQUISA DE EROSÃO COM SIMULADORES DE CHUVA, 1, Londrina, 1975. Resumos. Londrina: EMBRAPA, 1975. p.107-120.

ENGEL, F.L. Erosão hídrica sob diferentes estádios de crescimento da cultura da soja, em diferentes métodos de preparo do solo. Lages: Universidade do Estado de Santa Catarina, 2005. 82p. (Dissertação - Mestrado).

FOSTER, G.R. 1982. Modeling the erosion process. In: BASSELMAN, J.A. (Ed.). Hydrological modeling of small watersheds. St. Joseph: ASAE, 1982. p.297-300.
HARTWIG, R.O.; LAFLEN, J.M. A meterstick method for measuring crop residue cover. Journal of Soil and Water Conservation, v.33, p.90-91, 1978.

LEITE, D.; BERTOL, I.; GUADAGNIN, J.C.; SANTOS, E.J.; RITTER, S.R. Erosão hídrica em um Nitossolo Háplico submetido a diferentes sistemas de manejo sob chuva simulada: I. Perdas de solo e água. Revista Brasileira de Ciência do Solo, v.28, p.1033-1044, 2004.

LEVIEN, R.; COGO, N.P.; ROCKENBACH, C.A. Erosão na cultura do milho em diferentes sistemas de cultivo anterior e métodos de preparo do solo. Revista Brasileira de Ciência do Solo, v. 14 , p.73-80,1990.

MELLO, E.L.; BERTOL, I.; ZAPAROLLI, A.L.V.; CARRAFA, M.R. Perdas de solo e água em diferentes sistemas de manejo de um Nitossolo Háplico submetido à chuva simulada. Revista Brasileira de Ciênca do Solo, v.27, p.901-909, 2003.

MORAIS, L.F.B.; COGO, N.P. Comprimentos críticos de rampa para diferentes manejos de resíduos culturais em sistema de plantio direto em um Argissolo Vermelho da Depressão CentralRS. Revista Brasileira de Ciência do Solo, v.25, p.1041$1051,2001$.

SWANSON, N.P. Suggestions for use the rotating-boom field plot rainfall simulator to obtain data for application of the soil loss equation. Paraná: FAO, University of Nebraska, 1975. 6p. (Relatório de Consultoria).

VIEIRA, M.J.; COGO, N.P.; CASSOL, E.A. Perdas por erosão em diferentes sistemas de preparo do solo para a cultura da soja (Glycine max (L.) Merr.) em condições de chuva simulada. Revista Brasileira de Ciência do Solo, v.2, p.209-214, 1978.

WISCHMEIER, W.H.; SMITH, D.D. Predicting rainfall erosion losses: a guide to conservation planning. Washington: USDA, 1978. 58p. (Agricultural Handbook, 537).

Received April 13, 2006

Accepted March 02, 2007 